\title{
Analysis of Omission and Addition Errors Found in the Students' English Texts
}

\author{
Harisna Hikmah \\ ryshnano@unu-jogja.ac.id \\ Nahdlatul Ulama University Yogyakarta
}

\begin{abstract}
The research was done to find the aspects of omission and addition errors in English texts made by the students of MAN 3 Bantul. The research was a descriptive study which was conducted in MAN 3 Bantul. The data was collected by analyzing the students' writing. There were 20 exposition texts made by the eleventhgrade students of MAN 3 Bantul. The text is written in four different themes. After getting the data, the data were analyzed by identifying and deeply checking the students' errors according to the theory form James (1998). The data found then categorized by entering the data to the table based on the linguistic taxonomy and surface strategy taxonomy. There were many aspects of omission or addition errors found in this study. From the data analysis, the study found seven aspects of omission errors and six aspects of addition errors. The aspects of omission errors were omission of (1) to be, (2) article, (3) pluralization, (4) verb, (5) preposition, (6) pronoun, and (7) agreement. While the aspects of addition errors were addition of (1) preposition, (2) article, (3) conjunction, (4) to be, (5) sub clause marker, and (6) verb. It can be concluded that the students still have lack of grammatical mastery and implies that grammar should be inserted in the teaching and learning process. It implies that the students should be given enough opportunity in learning English grammar more. The teacher should also increase their awareness concerning with the errors made by the students. They have to give more emphasize and also feedback to increase the students' awareness in applying English grammar rule in creating sentence or texts.
\end{abstract}

Keywords: errors, omission, addition, students' writing, text

\section{INTRODUCTION}

In Indonesia, English is taught as an obligatory subject in Junior and Senior High School. As a foreign language, there are some obstacles faced by the students in learning English because the system of language is very different with the first language. The process of learning second or foreign language is totally different in nature from the process of primary acquisition or the first language, it is clearly said by Corder (1981). In mastering English as a foreign language, students should master the English skills, grammatical structure and vocabulary. 
This study focuses in analyzing the errors of omission and addition that found in the text made by students of eleventh grade of MAN 3 Bantul. Texts is chosen because by writing texts, students are exposure to do some stages. The stages that have to be done in writing a text are: (1) looking for ideas and conveying it cohesively and coherently, (2) designing the frame of writing, and (3) developing it into a good writing. It suits with Halliday and Hasan statement, they say that text refers to any passage, spoken or written of whatever length, that does form a unified whole.

In curriculum 2013, English is taught based on main competencies and also based competencies. The teacher must plan and develop their teaching and learning process based on this. And there are many kinds of text taught is senior high schools. Expository text is one of the text types taught in senior high school. In an expository text, the writer has to present one side of an issue. The aim of the text is persuading the readers or listeners by presenting one side of an argument. In developing this text, the students need ability in elaborating ideas into details and clear paragraphs. However, in creating a text, students usually face many obstacles. The students have to master grammar and punctuation as the aspects of writing to reach the goal. In fact, students still have difficulties dealing with the grammatical and punctuation mastery.

Dulay and Burt (1982: 138) state that people cannot learn language without making errors. Omission of errors is type of Errors happen because the learners were still lack of form or grammar that is supposed to have in the sentence but the learners omit or delete it. While addition is a type of error that happen when the students add an unnecessary word/phrase. By studying students' writing, the students' problems in writing can be found. Because writing is the most difficult skill in learning English. Writing skills are more complex than spoken skills and certainly difficult to teach. It requires not only grammatical and theoretical devises but also conceptual and judgmental elements. The study focuses on the investigation of omission and addition errors in English texts made by 20 students of MAN 3 Bantul. They were in the eleventh grade.

According to Dulay, Burt and Krashen (1982: 150-163), there are four categories of errors based on the surface strategy taxonomy. They are omission, addition, misformation, and misordering. James (1998:106) classifies the types of errors into six types. There are omission, addition, mis-formation, mis-ordering, mis-selection, and blends. Omission is the absence of one or more words that have to appear in a well-formed construction. ELTICS Vol.5, No.1, January 2020 
Addition is the appearance of an item which must not presence in a well-formed construction. Mis-formation is the incorrect form of the structure, and mis-selection is the use of the wrong words.

Error Analysis becomes an interesting issue in studies of second language acquisition. In language teaching and learning, error analysis can be used as a technique identify, classify, and finally find the students' difficulties in learning English. It suits with Hariri (2012: 4856) which states that EA is a systematic procedure in gathering, identifying, describing, then explaining and also evaluating errors from from the data then finally analyzing it.

There are some stages in analyzing students' errors. Based on Corder in Ellis and Barkhuizen (2005: 57), there are five steps in EA. The first is collection of samples. It can be done by gathering the students writing. The second step is identifying errors, it is done by underlining the item that contain errors. The third step is describing errors. In describing errors, the identified data should be classify based on the type of errors. The fourth step is explaining errors, and the last is evaluating the errors. Identifying the errors can be done to analyse the psychology factors why does the error exist.

Dealing with the type of errors, Dulay, Burt and Krashen (1982: 150-163), classifies errors into four categories based on the surface strategy taxonomy. They are omission, addition, misformation, and misordering. Omission can also be called as deletion. It is the missing of one or more items that must exist in a sentence or utterance. It happens if the lexical item which should be present is omitted or deleted. Addition error is error that can be identified by the presence of an item which must not appear in a sentence or utterance. Mis-formation errors is the wrong form of the structure. Mis-ordering errors occurs when the writer put an item in the incorrect place in a construction. Blends are errors happen when two grammatical forms are combined in creating an ungrammatical blend. It is also known as contamination or cross-association. Mis-selection is the wrong use of words or lexical items in a construction. It happens when the learners choose the wrong item.

Writing is one of the four skills in learning English that has to be mastered by the students. It is said that writing is the most difficult skill in learning English since it requires steps to accomplish. In writing a text, students need to do some steps. They need to plan, draft, review and revise their writing. It needs physical and a mental act. The physical act is done for pouring the ideas and a mental act is done for pouring opinions, ideas, and 
thinking in how to express and finally organize them into sentences, paragraphs and also texts.

\section{RESEARCH METHOD}

This research is a descriptive study since the data found are explained descriptively. The study is aimed on the investigation of omission and addition errors in the students' writings. It focuses on the aspects of omission and addition errors found in the English texts. The texts are expository texts which was divided into four different themes. The study was held in MAN 3 Bantul. The data were collected from 20 texts written by 20 students of eleventh grade of MAN 3 Bantul. The students were asked to make an Analytical Exposition text based on the topic given. The topics were: (1) the negative effects of narcotics, (2) being fat, (3) the prohibition of smoking in a public places, (4) benefits of using internet for students, and (5) fast foods. The students had to write an expository text in 60 minutes.

After collecting the students' text, the writer tried to identify and check the errors made by the students. It limited on the error of omission and addition. Then, the errors found in the text were underlined and put into the table or the data card. In this study, the researcher became the main instrument. The researcher carried out the study directly. Interrater and intrarater are used the trustworthiness of the data. The intrarater means the researcher read the data deeply and continuously. While the intrarater means the researcher asked an expert to validate the data found. In analyzing the data, the writer used three techniques, those are (1) identifying by underlining the errors, (2) classifying the omission and addition errors, and (3) coding the data found, and analyzing it using the theories from Dulay, Burt, and Krashen in Ellis (2003:56) and also James (1998: 145).

\section{RESULTS AND ANALYSIS}

The result of the data analysis shows that there are seven aspects of omission errors. Those are omission of (1) to be, (2) article, (3) pluralization, (4) verb, (5) preposition, (6) pronoun, and (7) agreement. Omission of pluralization found in the student's sentence. E.g. 
There is several step*(s) is can carry out to go against obesity. The plural noun is signed by the word several. It shows the number of the noun is more than one, so- $s$ or $-e s$ must be presented after the countable noun. The correct form will be: There are several steps to go against obesity. The other aspect of omission errors found in this study is omission of article. It can be seen from the sentence "It is dangerous, except for (the)*smoker that is also for all people in smoker surroundings." The sentence made by the student showed that the student did not put article (the) in front of the word smoker. Besides, the sentence has some errors also. The correct construction should be: It is dangerous, except for the smoker and also for all people surrounding. From the data calculation, the errors of omission can be seen as follows:

Table I. Aspects of Omission Errors in Students' Writing

\begin{tabular}{llc}
\hline No & \multicolumn{1}{c}{ Aspect of Omission } & Frequency \\
\hline $\mathbf{1}$ & omissions of to be & 33 \\
$\mathbf{2}$ & omissions of article & 16 \\
$\mathbf{3}$ & omissions of pluralization & 14 \\
$\mathbf{4}$ & omissions of verb & 14 \\
$\mathbf{5}$ & omissions of preposition & 13 \\
$\mathbf{6}$ & omissions of pronoun & 7 \\
\hline $\mathbf{7}$ & omissions of agreement & 6 \\
\hline
\end{tabular}

From the table, it can be seen that the highest frequency of omission errors found in the aspect of to be. The students omitted to be up to 33 times. After that, the omission happened on the aspects of article. Most of the students omitted the before the specific noun.

On the other hand, this study also found some errors of addition. The aspects of addition errors were addition of (1) preposition, (2) article, (3) conjunction, (4) to be, (5) sub clause marker, and (6) verb. Some examples of the sentence contains addition errors can be seen in the table below:

Table 2. Example of Addition Errors in Students' Writing

\begin{tabular}{cll}
\hline No & \multicolumn{1}{c}{ Sentence } & Aspect of addition \\
\hline $\mathbf{1}$ & $\begin{array}{l}\text { Firstly, the students can find their skill } * \text { in } \\
\text { here. }\end{array}$ & Addition of preposition \\
$\mathbf{2}$ & Because health is the expensive. & Addition of article \\
\hline
\end{tabular}


3 Firstly, the activities can * be give your more Addition of to be insight.

The first example showed that the student put unnecessary item 'in' in the sentence.

So the correct construction will be: Firstly, the students can find their skill here. The second example also showed the unnecessary item. The student put article 'the' before the word expensive. Grammatically, expensive is an adjective, and in the construction 'the' should be omitted. While the last sentence the student put the word be after can and before give. As we know that can is always followed by the verb base. So it should be 'Firstly, the activities can give your more insight'

From the data tabulation, the frequency of the aspect of addition errors can be seen as follows:

Table 3. Aspects of Addition Errors in Students' Writing

\begin{tabular}{clc}
\hline No & \multicolumn{1}{c}{ Aspect of Omission } & Frequency \\
\hline $\mathbf{1}$ & Addition of preposition & 16 \\
$\mathbf{2}$ & Addition of article & 11 \\
$\mathbf{3}$ & Addition of verb & 11 \\
$\mathbf{4}$ & Addition of conjunction & 9 \\
$\mathbf{5}$ & Addition of to be & 6 \\
$\mathbf{6}$ & Addition of sub-clause marker & 7 \\
\hline
\end{tabular}

From the table, it is clear that addition of preposition is the highest scores which has the meaning that students put some unnecessary preposition when they created their constructions. Followed by addition of article and verb placed in the second place. Whether the frequency of addition errors is less than omission errors, it still needs to be identified and analyzed since it is very important for the teacher to know how far the students' grammar mastery skill.

Considering to the aspects of omission and addition errors, it can be clearly seen that the aspects of omission and addition errors happens on putting the item of article, preposition and to be. These three components are included to the minimum requirement of grammatical pattern that the students have to be mastered when they were learning English. So, by seeing this, the competence of grammar should be placed in the teaching and learning process. Even if, in the implementation of curriculum 2013, grammar should be taught through texts. The teacher should give brief and clear explanation to the students ELTICS Vol.5, No.1, January 2020 
in applying the English grammar or structure well. However, the study still has some limitations since it only focuses on omission and addition errors. There are still some type of errors that can be explained in the students' writing.

\section{CONCLUSION}

The data results showed that there are seven aspects of omission errors and six aspects of addition errors, it implies that the students need more emphasize and opportunity to learn English grammar. It also implies that the English teachers should give and provide more time in giving emphasis on the aspects of the students' errors when they check their students' writings. Because by doing the analysis on the students' errors, the teacher can determine some source in developing syllabuses and materials better. It can also help teacher in prepare the techniques and also media according to the students' necessity, especially in learning grammar. Giving feedback to the students based on the errors found in their writing will also help the students in being more aware in applying the pattern and rule in constructing their sentence or texts. The English teachers should give explanation as the feedback for them through various strategies for the students. The feedback and explanation should be given based on the level of the proficiency that the students have. Moreover, the English teacher should develop their ability in improving the students' language awareness. To raise the teachers' awareness on how they teach can be done by engaging themselves in self-observation or self-monitoring.

\section{REFERENCES}

Corder, S.P. Error analysis and interlanguage. Oxford: Oxford University Press. 1981

Dulay, H., Burt, M., \& Krashen,S. Language two. New York: Oxford University Press. 1982

Ellis, R. \& Barkhuizen G. Analysing learner language. New York: Oxford University Press. 2005

Haliday, M.A. K \& Hasan, R. Cohesion in English. London: Longman Group Ltd. 1976 Hariri, M. Taxonomy of morpho-syntactic errors and error analysis. Research journal of applied sciences, engineering and technology, vol 4 issues 22, page 4856-4860, 2012. Retrieved on 27 Agustus 2015, from www.maxwellsci.com. 2012 
James, C. Errors in language learning and use. London: Longman. 1998

Liu, M. An investigation of syntactic errors in Chinese undergraduate efl learners: a cohort study. international journal of applied linguistics \& English literature. Vol. 2 No. 4; July 2013. Retrieved on 12 August 2015, from http://www.journals.aiac.org.au/index.php/IJALEL. 2013

\section{BIOGRAPHIES OF AUTHORS}

Harisna Hikmah, English Education Department of Nahdlatul Ulama University of Yogyakarta, graduated from English Department of State University of Yogyakarta in 2008 she continued to study in State University of Yogyakarta in 2013 in Applied Linguistics study program specification of English Education Program. She did research on linguistics and also in language teaching. 